\title{
MATERIALES INÉDITOS DE SETEFILLA (LORA DEL RÍO, SEVILLA)
}

\section{UNPUBLISHED MATERIALS FROM SETEFILLA (LORA DEL RÍO, SEVILLA)}

\author{
por \\ INMACULADA LADRON DE GUEVARA SANCHEZ \\ MILAGROSA SANCHEZ ANDREU \\ MERCEDES RODRIGUEZ DE ZULOAGA \\ MARIA LAZARICH GONZALEZ
}

\begin{abstract}
RESUMEN Estudio de un conjunto cerámico de amplia tipología, recogido en La Mesa de Setefilla, que ofrece una cronología que abarca desde el siglo VIII al VI a.C.

ABSTRACT A study of pottery collection of varied typology, collected in La Mesa de Setefilla, chronologically dated from the 8 th century to the 6th century B.C.
\end{abstract}

\section{EL YACIMIENTO DE SETEFILLA}

Setefilla constituye, desde el punto de vista arqueológico, un conjunto que puede subdividirse en varios sectores (Aubet y otros 1983). De ellos, conviene destacar aquí el representado por el tell de La Mesa del Santuario y el de la necrópolis tumular situada al pie del camino de acceso a la ermita actual (fig. 1). Porque es en ambos núcleos donde se ha detectado hasta la fecha un horizonte cultural contemporáneo al que pertenecen los documentos que se estudian en el presente trabajo.

La Mesa de Setefilla es una plataforma, ligeramente inclinada hacia el S.-SE., que sirve hoy de emplazamiento al Santuario de la Virgen del mismo nombre. En su extremo Norte se inauguró en el Bronce Antiguo un poblado que es el origen del cabezo artificial sobre el que se colocó en la Edad Media el castillo que corona la cima. Este montículo ha sido objeto de varias campañas de excavación, mediante las cuales se ha puesto al descubierto una secuencia estratigráfica que comenzó a depositarse al menos hacía el siglo XVI a.C. (Aubet y otros 1983; Serna, 1989). Algunos autores han argumentado que esta acumulación no debió comenzar en época tan antigua (Martín de la Cruz, 1987: 203-204), 
pero dicha corrección ha sido fuertemente constestada por otros estudios (Escacena y Belén, 1991: 1315). En cualquier caso, interesa más aquí pararnos en el horizonte correspondiente al Bronce Final y a la Fase Orientalizante, periodos con los que muestran relación los materiales que ahora se presentan.

Según la revisión estratigráfica propuesta por Escacena y Belén (1991: 13-15), esta otra fase se inicia en Setefilla en el siglo IX a.C. aproximadamente, en el estrato XIII, dando lugar a los niveles correspondientes a época tartésica. Parece que dicha ocupación tardía de la Edad del Bronce no tuvo que ver mucho con el anterior establecimiento del Bronce Medio, pues se ha sospechado un hiato importante entre uno y otro poblados (Belén y Escacena, e.p.).

La secuencia estratigráfica concluye en Setefilla, por lo que a los tiempos protohistóricos se refiere, hacia los momentos iniciales de la segunda Edad del Hierro, como consecuencia de la crisis general que a fines del siglo VI a.C. afectó al mundo tartésico.

La documentación que constituye el objeto de estudio del presente artículo pertenece, como se verá, a la etapa orientalizante de la ocupación tartésica de Setefilla. A ella corresponden también los enterramientos de su necrópolis tumular. Ésta comenzó a excavarse a principios de siglo (Bonsor y Thouvenot, 1928) y ha proseguido en la década de los setenta por parte de un equipo dirigido por M.E. Aubet (Aubet, 1975, 1978, 1980-81 y 1982).

\section{CIRCUNSTANCIAS DEL HALLAZGO}

Los objetos que componen el lote aquí estudiado se descubrieron casualmente en 1985, al construirse una canalización de aguas al pie de la fachada meridional de la ermita de Setefilla. Todo el conjunto fue recogido por D. Blas Cosano, santero de la Virgen, quien tuvo la precaución, alertado por cómo había visto sacar a los arqueólogos los materiales durante las excavaciones, de separar los hallazgos en función de su posición estratigráfica. Por él sabemos que las presentes piezas se encontraban contenidas en un nivel de tierras oscuras, arcillosas y compactas, que constituían la primera capa acumulada sobre la superficie rocosa de la colina. Encima de este estrato existía otro que contenía fundamentalmente materiales medievales y modernos, y que componía el nivel actual del suelo. Todo lo que aquí se estudia procede, pues, de una misma unidad sedimentaria, lo que apoya en principio la homogénea cronología de los distintos documentos.

La secuencia advertida en esta parte Sur de la ermita es, en síntesis, parecida a la del Corte D, que se abrió durante la campaña de 1979 en un punto intermedio entre el santuario y el tell del castillo. Dicha cuadrícula demostró una ocupación máxima de La Mesa de Setefilla en época orientalizante tartésica, lo que de nuevo viene avalado por los presentes hallazgos (Aubet y otros 1983: 128-129).

Vaya desde aquí nuestro agradecimiento a D. Blas Cosano por el celo mostrado a la hora de rescatar estos objetos, a Dña. $M^{a}$ E. Aubet Semmler por habernos permitido estudiarlos y publicarlos y a D. J.L. Esacacena Carrasco por brindarnos la oportunidad de llevarlo a cabo.

\section{DOCUMENTACION}

\section{III.1. Introducción}

El elevado número de piezas que componen este estudio nos ha obligado a presentar una selección de los materiales hallados en función de su representatividad tipológica y decorativa. 


\section{III.2. Cuadro de descripción}

Las características de este conjunto cerámico se han reflejado en un cuadro descriptivo (fig.2). En el eje de abcisas hemos dispuesto la signatura y el número de catálogo otorgado a cada fragmento. En el eje de coordenadas aparece la nomenclatura para efectuar la clasificación formal de los mismos.

La información recogida queda así expuesta de una forma más clara y simple, permitiendo una lectura global de los rasgos de los materiales hallados.

\section{ESTUDIO CRITICO DE LA DOCUMENTACION}

\section{IV.1. Recipientes a mano}

\section{IV.I.a. Cerámica sin tratamiento}

Este grupo consta únicamente de dos fragmentos (fig.3: SE-85/23 y 97). El primero (fig.3,1) se define como cuenco carenado, de borde exvasado y labio redondeado. Su diámetro es de $38 \mathrm{cms}$. y su tratamiento simplemente rugoso. En la provincia de Huelva hemos encontrado diversos ejemplares en los yacimientos de San Bartolomé de Almonte (Ruiz Mata y Fernández Jurado, 1986: láms. LXXXIX,1118; LXXII,994; LXXIV,1003) y de Tejada la Vieja (Fernández Jurado, 1987: lám. XIII,5). Su cronología se sitúa entre finales del siglo VIII y el siglo VII a.C. El segundo (fig.3,2) es un recipiente de tendencia globular, con borde redondeado y un poco exvasado, cuya silueta recuerda ligeramente el perfil en "S". Su boca mide $43 \mathrm{cms}$. y su tratamiento, al igual que el anterior, es rugoso. Por lo que se refiere a la provincia de Sevilla, sus paralelos se localizan en el Cerro Macareno (Pellicer y otros 1983: fig. 66,562). En la de Huelva, se han encontrado ejemplares semejantes en San Bartolomé de Almonte (Ruiz Mata y Fernández Jurado, 1986: láms. XXXVIII,532; XCI, 1153). La datación para esta forma oscila entre la segunda mitad del siglo VIII y el siglo VII a.C.

\section{IV.1.b. Cerámica con decoración digitada}

Los fragmentos encontrados con decoración de impresiones digitales (fig.4; SE-85/100-101)) mantienen la tipología habitual en este conjunto cerámico. La vasija en su conjunto presenta un perfil sinuoso en forma de "S"; el borde se encuentra exvasado, permitiendo así una amplitud mayor a la boca, que suele mantener un diámetro, en los nuestros, que oscila entre los $46-47 \mathrm{cms}$.; el labio se suele presentar ligeramente redondeado. El tratamiento en estas piezas es mínimo y, en general, queda reducido al hombro del recipiente para poder situar con facilidad la banda decorativa, mientras que el resto del cuerpo ofrece un aspecto rugoso. Las características técnicas señalan que estas ollas o recipientes tienen una función específica muy concreta: el almacenamiento. No obstante, aquéllas con bocas menos amplias suelen utilizarse directamente sobre el hogar para cocinar, pues los restos de fuego así parecen indicarlo.

El reparto geográfico de esta cerámica decorada con impresiones digitales es muy amplio. Los fragmentos seleccionados en nuestro estudio presentan paralelos en la provincia de Huelva, en concreto en los yacimientos de Tejada la Vieja (Fernández Jurado, 1987: láms. XXII,2 y XXXII,4), de San Bartolomé de Almonte (Ruiz Mata y Fernández Jurado, 1986: fondo II) y del Cerro Salomón (Blanco y otros 1970: cata D) entre otros; en la provincia de Sevilla han entregado tipos similares el Cerro 
Macareno (Pellicer y otros 1983: estrato II) y Carmona (Pellicer y Amores 1985: estrato X) por ejemplo; finalmente, en la provincia de Córdoba existen en el corte estratigráfico abierto en la Colina de los Quemados (Luzón y Ruiz Mata 1973: estratos 12-11).

La cronología en todos ellos es uniforme, abarcando un periodo comprendido entre finales del siglo VIII y mediados del VI a.C.

\section{IV.1.c. Cerámica bruñida sin decoración}

La selección de fragmentos cerámicos modelados a mano y con tratamiento bruñido (fig. 5) permite elaborar diferentes grupos de estudio en virtud, como anteriormente mencionamos, de su tipología. En conjunto hemos diferenciado entre: a) Cuencos carenados con bordes casi rectos o bordes exvasados; b) Platos de perfil tendido y labios redondeados y platos con una carena ligeramente marcada; y c) Ollas de tendencia globular, cuello recto y borde exvasado.

Los cuencos presentan un diámetro que oscila entre los 39-21 cms., los platos entre los $28-21 \mathrm{cms}$.; las ollas, al ser recipientes de mayores dimensiones, aumentan en consecuencia sus diámetros, situándose éstos entre los 58-38 cms.. Todos estas formas ofrecen un tratamiento generalmente bruñido, aunque en ocasiones aparecen espatuladas o solamente alisadas.

La pertenencia de estos fragmentos a vajillas muy conocidas en el momento cultural que analizamos hace que los paralelos sean muy numerosos, por lo que nos abstenemos de mencionar yacimientos concretos donde este tipo de recipientes se ha encontrado.

Mención especial merece un plato del que hemos podido obtener el perfil completo (fig. 10,2;SE$85 / 60$ ). Su diámetro alcanza los $30 \mathrm{cms}$., y su tratamiento tanto exterior como interior ofrece un bruñido de muy buena calidad. Tiene paralelos en El Carambolo (Carriazo 1978: fig. 518).

El periodo cronológico en el que quedan incluidas abarca desde finales del siglo VIII a mediados del siglo VI a.C.

\section{IV.1.d. Cerámica con decoración bruñida}

Entre los fragmentos hallados, los que llevan decoración bruñida constituyen el conjunto más numeroso de este estudio (figs. 6-9). Como en el apartado anterior, presentaremos el material dividiéndolo por grupos tipológicos para facilitar la descripción. De este modo distinguiremos entre: a) Platos con línea de carena ligeramente marcada al exterior, bordes poco exvasados y labios redondeados o algo apuntados, diámetros entre 20 y $26 \mathrm{cms}$. y tratamiento casi siempre alisado y/o bruñido; b) Platos sin carena, con borde poco exvasado y a veces engrosado al interior, con diámetros entre 20 y $30 \mathrm{cms}$. y tratamientos similares a las piezas del anterior; c) Cuencos carenados con bordes exvasados y labios redondeados, con diámetros entre los 18 y $26 \mathrm{cms}$. y con las superficies alisadas o, a veces, espatuladas o bruñidas; y d) Cuencos con línea de carena muy marcada tanto al exterior como al interior, bordes exvasados y labios orientados al exterior, con diámetros entre los 20 y $30 \mathrm{cms}$. y tratamiento que en conjunto presenta un alisado en ambas caras.

Estas piezas muestran una decoración bruñida que permite observar a partir de unas normas básicas distintos diseños. Deben señalarse, entre ellos, los siguientes:

- Agrupación de haces de líneas que parten de la zona inferior del borde (éste se bruñe totalmente) del vaso y se dirigen hacía el centro del mismo.

- Se trata de una variante del primer diseño, que puede aparecer representado de un modo más simple y mostrar tan sólo líneas sin agrupar, es decir, un rayado continuo. 
- Otro motivo, partiendo de la misma idea, reúne estos haces en sentido oblicuo, ofreciendo una disposición similar a los denominados "dientes de lobo".

- Naturalmente, incluidos en esta gama decorativa hemos encontrado el tema normalmente llamado "de retícula bruñida".

Queremos apuntar, sin embargo, que estas agrupaciones no forman conjuntos estancos, sino que por el contrario pueden aparecer formando distintas combinaciones.

Hemos dejado para el final el análisis de dos platos que muestran ciertas características especiales por lo peculiar de sus decoraciones. Uno de ellos, de boca muy abierta, se ha conservado en sus tres cuartas partes, y presenta tratamiento alisado por ambas caras; ofrece como motivo decorativo la "retícula" (fig. 7; SE-85/68); El otro, de perfil carenado y en el que se ha empleado la técnica del bruñido para ambas caras, muestra como diseño decorativo un motivo floral que podría recordar los aparecidos en la cerámica orientalizante hallada en la misma Setefilla (Aubet y otros 1983: fig. 48,333 y 336) o los encontrados en las placas de marfíl del túmulo $H$ de su necrópolis (Aubet, 1981-82: fig.11), de los túmulos de incineración de la necrópolis de Bencarrón (Aubet, 1981-82: figs. 5 y 6), de Acebuchal (Bonsor, 1899: fig. 24), de Alcantarilla (Bonsor, 1899: fig.50) y de Cruz del Negro (Aubet, 1979: fig. 2,3 y fig. 7).

En el análisis de los motivos bruñidos hemos podido comprobar que el conjunto obtenido se asemeja más a los ejemplares hallados en estratigrafías de las provincias de Sevilla y Córdoba que a las piezas de los yacimientos de la provincia de Huelva.

Desde el punto de vista tipológico, nuestras piezas son comparables con las encontradas en el Cerro Salomón (Blanco, y otros 1969: fig. 16,11), en San Bartolomé de Almonte (Ruiz Mata y Fernández Jurado, 1986: láms. XLVIII,652; XXX,382; LXXII,994; XXXVI,485 y LXV,909) y en el Cabezo de San Pedro (Blázquez y otros 1989: lám. XXI-e), por lo que se refiere a la provincia de Huelva. En el área de Sevilla, hemos hallado ejemplares similares en la estratigrafía de la propia Mesa de Setefilla (Aubet y otros 1983: figs. 59,1; 26,87; 41,238,239 y 240; 42,261; 43,284; 47,326 у 328; 34,177 у 36,192), en el corte CA-80/B de Carmona (Pellicer y Amores, 1985: fig. 46,8) y en los túmulos A y B de la necrópolis de Setefilla (Aubet, 1975: seps. 21,1; 19,3; 15,2; 54,1; 22,2; 24,3; 25,2; 29,2; у 36,2. Aubet, 1978: sep. 25,2).

El marco cronológico en que se incluye este conjunto cerámico abarca desde mediados del siglo VIII hasta el VI a.C. de una manera global; sin embargo, hay fragmentos en que la cronología se nos remonta hasta finales del siglo IX a.C.; del mismo modo, y en sentido inverso, otros nos la rebajan hasta el siglo $\mathrm{V}$ a.C.

\section{IV.2. Recipientes a torno}

\section{IV.2.a. Cerámica gris}

La cerámica realizada a torno, con tratamiento bruñido y de color gris, nos introduce en este segundo apartado de nuestro estudio (fig. 11). El escaso número de fragmentos aparecidos nos permite tan sólo valorar de un modo global este conjunto cerámico.

Poseemos ejemplares que podíamos definir como platos de casquete semiesférico y arandela en el cuello, con labios redondeados y otros que pueden catalogarse de platos de amplia boca con borde exvasado y labio redondeado. En este segundo grupo hemos de señalar la existencia de un fragmento 
perteneciente a un platito que tiene un diámetro de $12 \mathrm{cms}$.. En general las dimensiones de éstos oscilan entre los 18 y los $36 \mathrm{cms}$. El tratamiento muestra en todas las piezas estudiadas un bruñido de excelente calidad, que llega a producir en muchos fragmentos un efecto metálico.

Varios ejemplares de esta cerámica gris son fondos de base plana correspondientes a la forma 16 de Caro Bellido (1989).

Como en otros apartados de este estudio, mencionamos aparte un fragmento perteneciente a un plato con línea de carena muy marcada al exterior e interior, borde exvasado y labio con orientación acentuada hacía el exterior (fig. 10,1; SE-85/70). La amplitud de su boca es de $62 \mathrm{cms}$. y su estado de conservación es bastante bueno.

Ejemplares similares a los nuestros hemos detectado en los yacimientos de Tejada la Vieja (Fernández Jurado, 1987: láms. XXV,11; XI,5; LIX,1; y LX,28), del Cabezo de San Pedro (Del Amo y Belén, 1981: fig. 7,4), en el Cabezo de La Esperanza (Belén, y otros 1977: 108,3), en la necrópolis de La Joya (Garrido y Oorta, 1978: tumba 12,13) y en la necrópolis de Medellín (Almagro-Gorbea, 1977: 104).

Las piezas de cerámica gris incluidas en nuestro estudio se inscriben en un marco cronológico que abarca desde el siglo VIII al VI a.C.

\section{IV.2.b. Cerámica con decoración pintada}

\section{IV.2.b.1. Fragmentos con forma}

Tres fragmentos responden a estas características (fig. 12). Sus perfiles definen: a) vasija globular, de cuello exvasado y labio redondeado, con boca de $23 \mathrm{cms}$. de diámetro y decoración a base de una capa de pintura de color rojo vinoso tanto al exterior como al interior (fig. 12,3; SE-85/89); b) vasija globular, con borde en arandela y labio redondeado, abertura de $17 \mathrm{cms}$. y decoración consistente en una capa de pintura roja que cubre por completo la cara externa. En su parte interna se aprecia una banda de pintura del mismo tono que la exterior y que se extiende desde el borde de la vasija hacia el interior, ocupando $1,5 \mathrm{cms}$. (fig. 12,2; SE-85/91); c) fondo de base plana decorado en su interior con una capa de pintura roja que lo cubre por completo, mientras que la cara externa aparece cubierta por una banda de color rojo de $1,5 \mathrm{cms}$. de anchura y distante $2,5 \mathrm{cms}$. de la base (fig. 12,5; SE-85/95).

Fragmentos con características tipológicas similares hallamos en San Bartolomé de Almonte (Ruiz Mata y Fernández Jurado, 1986: láms. CXII,1429 y CXV,1481-82-83), en Tejada la Vieja (Fernández Jurado, 1987: lám. V,9), en el Cabezo de la Esperanza (Belén, y otros 1977: fig. 167,7) y en el Cabezo de San Pedro (Del Amo y Belén 1981: fig. 23,6 y 12), yacimientos ubicados todos en la provincia de Huelva. En la zona de Sevilla se detectan ejemplares como los nuestros en las estratigrafías del corte CA-80/A de Carmona (Pellicer y Amores, 1985: fig. 32,20) y del Cerro Macareno (Pellicer y otros 1983: fig. 42,1426).

Por lo que respecta al período cronológico al que se pueden atribuir, nuestros fragmentos ocupan los siglos V y IV a.C.

\section{IV.2.b.2. Fragmentos amorfos}

Hemos realizado un apartado independiente para los fragmentos que presentan decoración pintada sin tipología concreta. Constituyen un grupo homogéneo que se caracteriza por poseer bandas de color vinoso oscuro entre filetes o, a veces, líneas negras combinadas con bandas de color crema. 
Mención especial merece un fragmento amorfo con decoración de bandas con la combinación cromática negro-crema-rojo-crema-rojo-crema-negro-rojo; este tiesto lleva además unas finas incisiones situadas sobre el arranque de un asa trigeminada (fig. 12,1). Paralelos a esta pieza hemos encontrado en las estratigrafías de Montemolín (Cháves y De la Bandera, 1986: figs. 1; 4,c y 6) y de Carmona (Pellicer y Amores, 1985: figs. 23,11 y 35,15) entre otras, donde se han datado en el siglo VII a.C.

\section{IV.3. Otros materiales}

En este apartado incluiremos un grupo de objetos que por sus características no hemos creído conveniente introducir en los apartados anteriores (figs. 13-14).

En primer lugar mencionaremos la existencia de una figura zoomorfa de bulto redondo y moldeada en barro. Podría tratarse de un caballo, ya que, aunque carece de cabeza y tiene rotas las extremidades, pueden apreciarse con relativa claridad las crines y el arranque de la cola. No hemos hallado en yacimientos penínsulares figuritas en barro similares a la de Setefilla. No obstante, existen paralelos en bronce (Nicolini, 1966: tal. 37. Melida, 1900: 40). Caballos de barro aparecen en la necrópolis de Salamina, en Chipre, con una cronología entre los siglos VI y IV a.C. (Karageorghis, 1974: lams. XLI, 118 y CLXVI, 237 y 203).

El segundo objeto que presentamos es un pie de copa hecho en cerámica a mano, bruñido y muy similar a los hallados en los túmulos A y B de la necrópolis de Setefilla, aunque estos ejemplares presentan decoración pintada (Aubet, 1975: figs. 23 y 39; 1978: fig. 17). Copas con pies parecidos al nuestro se documentan también en momentos argáricos, pero con su superficie espatulada (Molina y Pareja, 1975: fig. 17). Los ejemplares funerarios de Setefilla tienen una cronología de los siglos VII y VI a.C., mientras que las argáricas están datadas en fechas mucho más antiguas.

Dentro de este grupo insertamos también una pieza cerámica en forma de estrella de cuatro puntas, de la que desconocemos su función y a la que no le hemos hallado paralelos exactos. Un ejemplar similar fue encontrado en el Cerro Macareno, en concreto en niveles del periodo Ibérico final, pero con una perforación central, lo que hace a sus excavadores describirla como pondus (Pellicer, y otros 1983: fig. 28,1821 ). Nuestro ejemplar carece de orificio central, aunque posee un difuso círculo impreso que nos hace pensar en una posible perforación.

Asimismo, se incluyen en este apartado una cuenta de piedra de color verde y sección oval y un objeto cerámico que, por su tipología, recuerda las pesas de red, y para el que tampoco conocemos paralelos.

\section{CONSIDERACIONES FINALES Y VALORACION}

$\mathrm{El}$ análisis del conjunto material que recoge nuestro trabajo nos ha permitido comprobar su homogeneidad cronológica a pesar de las condiciones en las que se realizó la recogida de las piezas. El elevado número de documentos nos ha proporcionado un amplio cuadro tipológico que data el conjunto, en líneas generales, entre los siglos VIII y VI a.C., si bien existe cierta tendencia hacia los momentos finales de esas fechas. 


\section{BIBLIOGRAFIA}

ALMAGRO-GORBEA, M. (1977): El Bronce Final y el Peitiodo Orientalizante en Extremadura. Madrid. AUBET, M.E. (1975): La necrópolis de Setefilla en Lora del Río. Túmulo A. Barcelona.

(1978): La necrópolis de Setefilla en Lora del Río, Sevilla (Túmulo B). Barcelona.

(1979): "Marfiles fenicios del Bajo Guadalquivir (I): Cruz del Negro", Studia Archaeologica 52: 6-67.

(1980-81): "Nuevos hallazgos en la necrópolis de Setefilla", Mainake II-III: 87-98.

(1981-82): "Marfiles fenicios del Bajo Guadalquivir: Bencarrón, Santa Lucía y Setefilla", Pyrenae 17-18: $231-79$.

(1982): "Los enterramientos bajo túmulo de Setefilla (Sevilla)", Huelva Arqueológica VI: 49-61.

AUBET, M.E. y otros. (1983): “La Mesa de Setefilla. Lora del Río (Sevilla) Campaña de 1979”, E.A.E. 122.

BELEN, M. y otros. (1977): "Los orígenes de Huelva. Excavaciones en los cabezos de San Pedro y La Esperanza" Huelva Arqueológica III.

BELEN, M. y ESCACENA, J.L. (e.p.): "Las comunidades prerromanas de Andalucía occidental", Congreso de Paletnología. Madrid.

BONSOR, G. (1899): "Les colonies agricoles préromaines de la vallée du Bétis", Revue Archaeologique XXXV.

BONSOR, G. y THOUVENOT, R. (1928): "Nécropole iberique de Setefilla. Lora del Río (Sevilla)", Bibliothèque de l'Ecole des Hautes Etudes Hispaniques, fasc. XIV. Bordeux.

BLANCO, A. y otros. (1970): Excavaciones arqueológicas en el Cerro Salomón, Riotinto (Huelva). Sevilla.

BLAZQUEZ, J.M ${ }^{\mathrm{a}}$ y otros. (1989): "Excavaciones en el Cabezo de San Pedro", Huelva Arqueológica I. 2a Reedición.

CARO BELLIDO, A. (1989): La cerámica gris a torno tartesia. Cádiz.

CARRIAZO, J. de M. (1973): Tartessos y El Carambolo. Madrid.

CHAVES, F. y DE LA BANDERA, M.L. (1986): "Figürlich verzierte Keramik aus dem Guadalquivir-Gebiet. Die Funde von Montemolín (Bei Marchena, Prov. Sevilla)", M.M. 27: 117-150.

DEL AMO, M. y BELEN, M. (1981): "Estudio de un corte estratigráfico en el Cabezo de San Pedro", Huelva Arqueológica V: 57-144.

ESCACENA, J.L. y BELEN, M (1991): "Sobre la cronología del horizonte fundacional de los asentamientos tartésicos", Cuadernos del Suroeste 2: 9-42.

FERNANDEZ JURADO, J. (1987): “Tejada la Vieja: una ciudad protohistórica”, Huelva Arqueológica IX.

GARRIDO, J.P. y ORTA, E.M. (1978): “Excavaciones en la necrópolis de «La Joya», Huelva”, E.A.E. 96.

KARAGEORGHIS, V. (1974): Excavation in the Necropolis of Salamis III. Nicosia.

LUZON, J.Ma y RUIZ MATA, D. (1973): Las Raíces de Córdoba. Estratigrafía de la Colina de los Quemados. Córdoba.

MARTIN DE LA CRUZ, J.C. (1987): “El LLanete de los Moros. Montoro, Córdoba. E.A.E. 187.

MELIDA, J.R. (1900): "La estación de bronces antiguos de D. Antonio Vives", RABM IV.

MOLINA, F. y PAREJA, E. (1975): "Excavaciones en La Cuesta del Negro, Purullena (Granada)”, E.A.E. 86.

NICOLINI, G. (1966): "Les bronzes votives iberiques de la Préhistoriche Steatssammhung, München", M.M. 7.

PELLICER, M y AMORES, F. (1985): "Protohistoria de Carmona. Los cortes estratigráficos CA-80/A y CA-80/ B", Noticiario Arqueológico Hispánico 22: 55-190.

PELLICER, M. y otros. (1983): "El Cerro Macareno", E.A.E. 124.

RUIZ MATA, D. y FERNANDEZ JURADO, J. (1986): "El yacimiento metalúrgico de época tartésica de San Bartolomé de Almonte (Huelva)", Huelva Arqueológica VIII.

SERNA, M.R. (1989): Bases para el estudio de la Edad del Bronce en el Valle del Guadalquivir: la secuencia estratigráfica de Setefilla. Santander. Microfilm. 


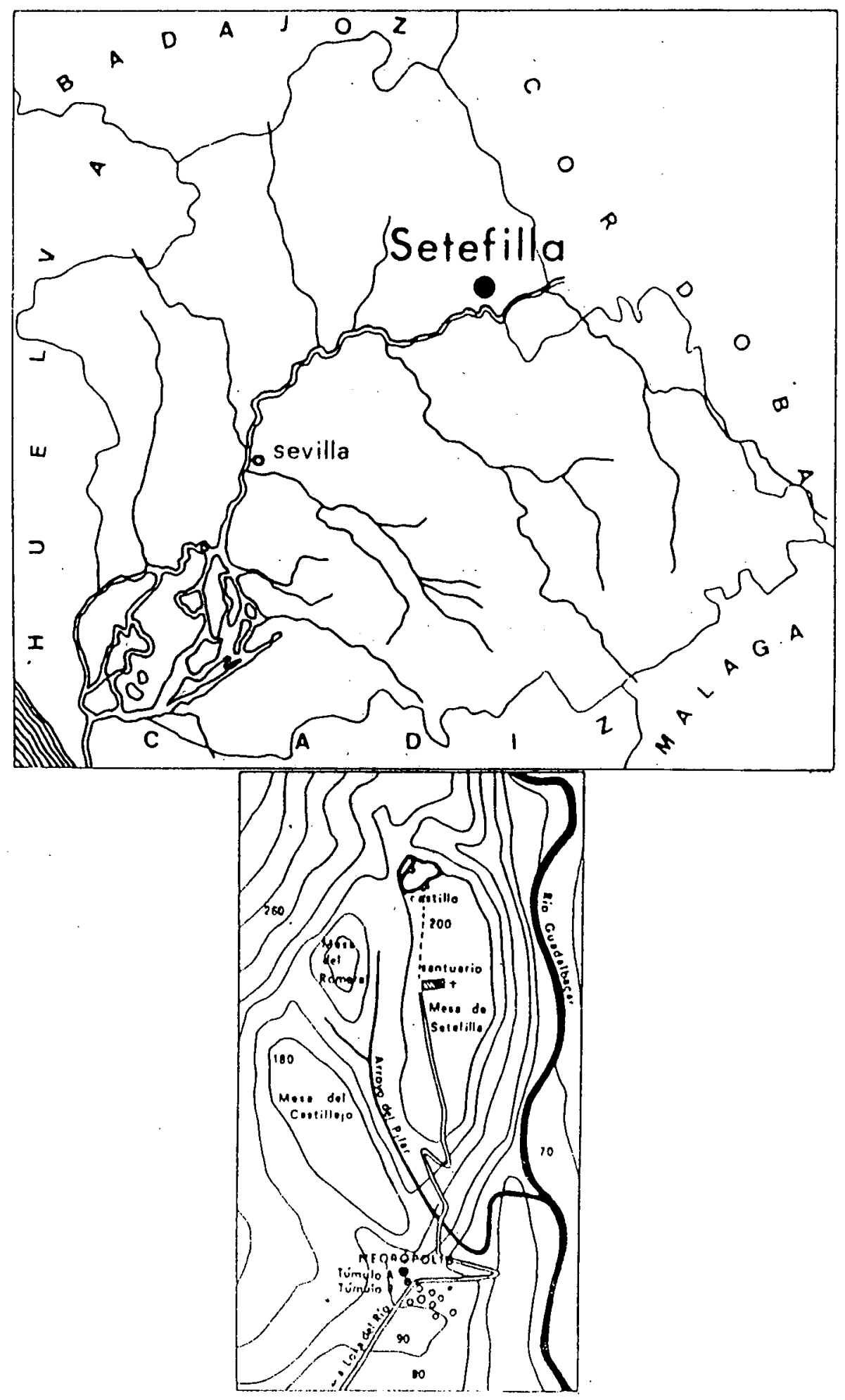

Fig. 1: Localización geográfica del yacimiento. 


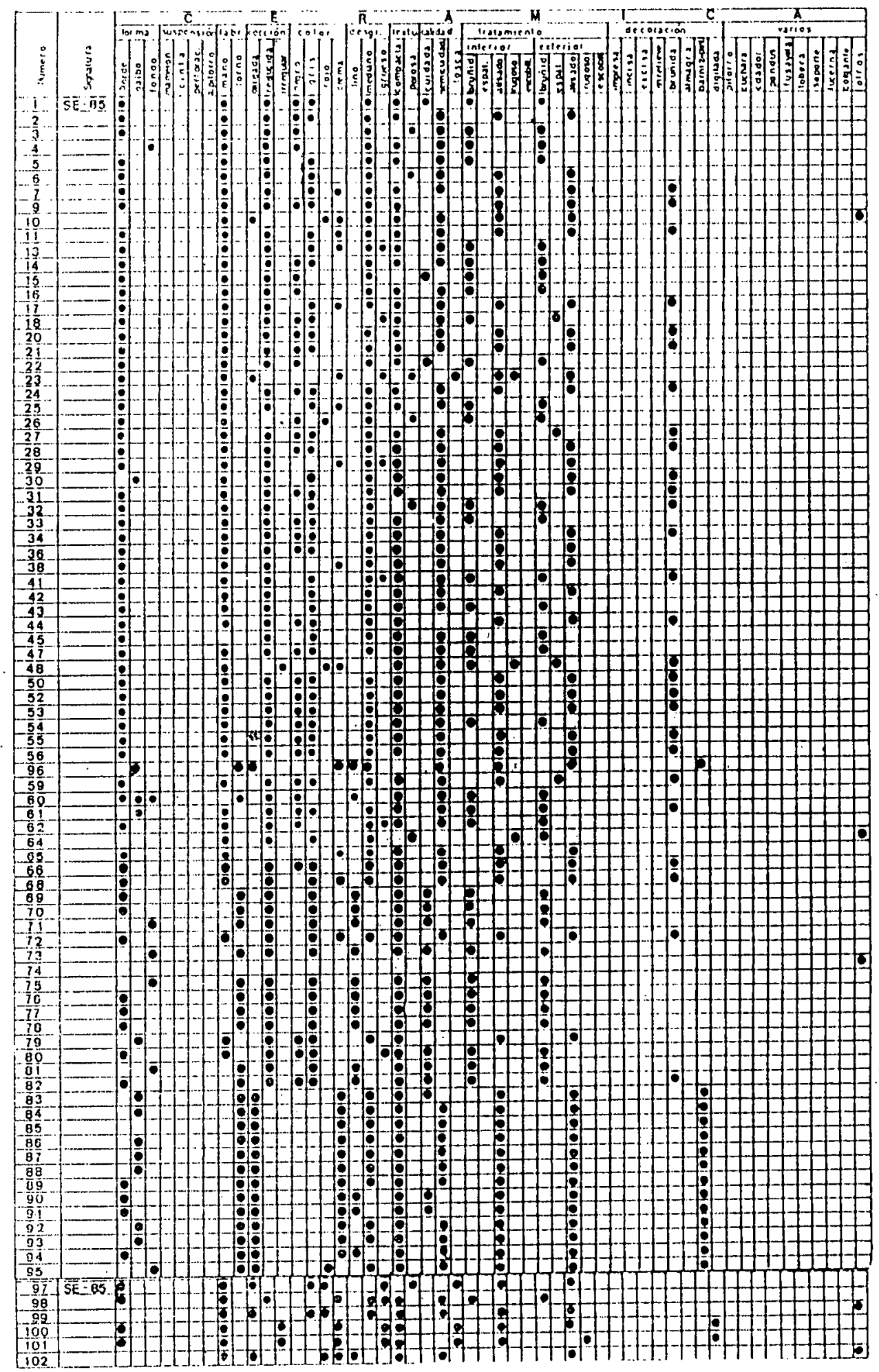

Fig. 2: Cuadro de descripción. 

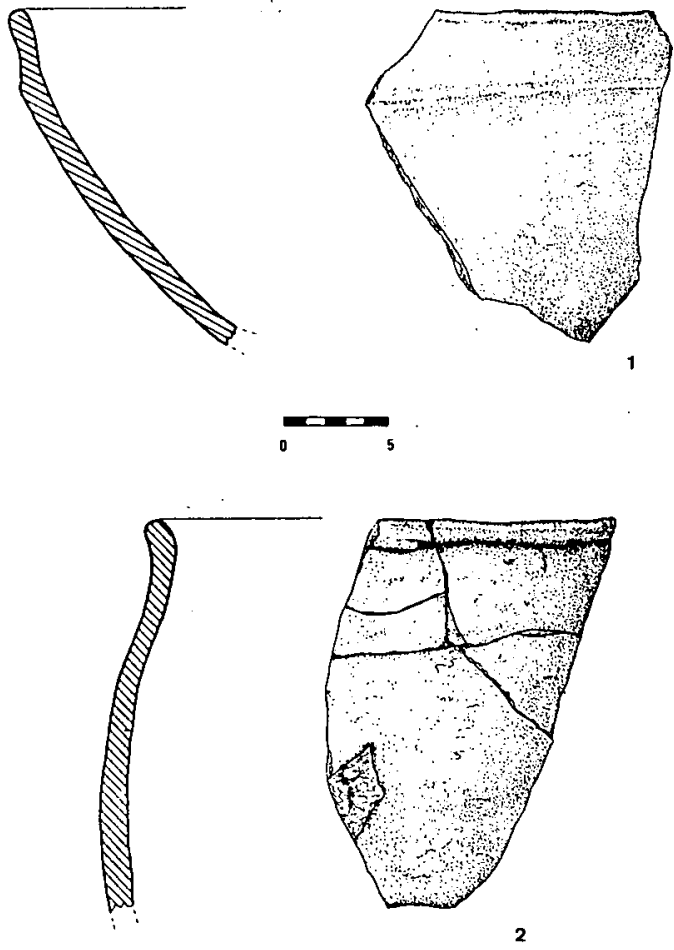

Fig. 3: Cerámica sin tratamiento.
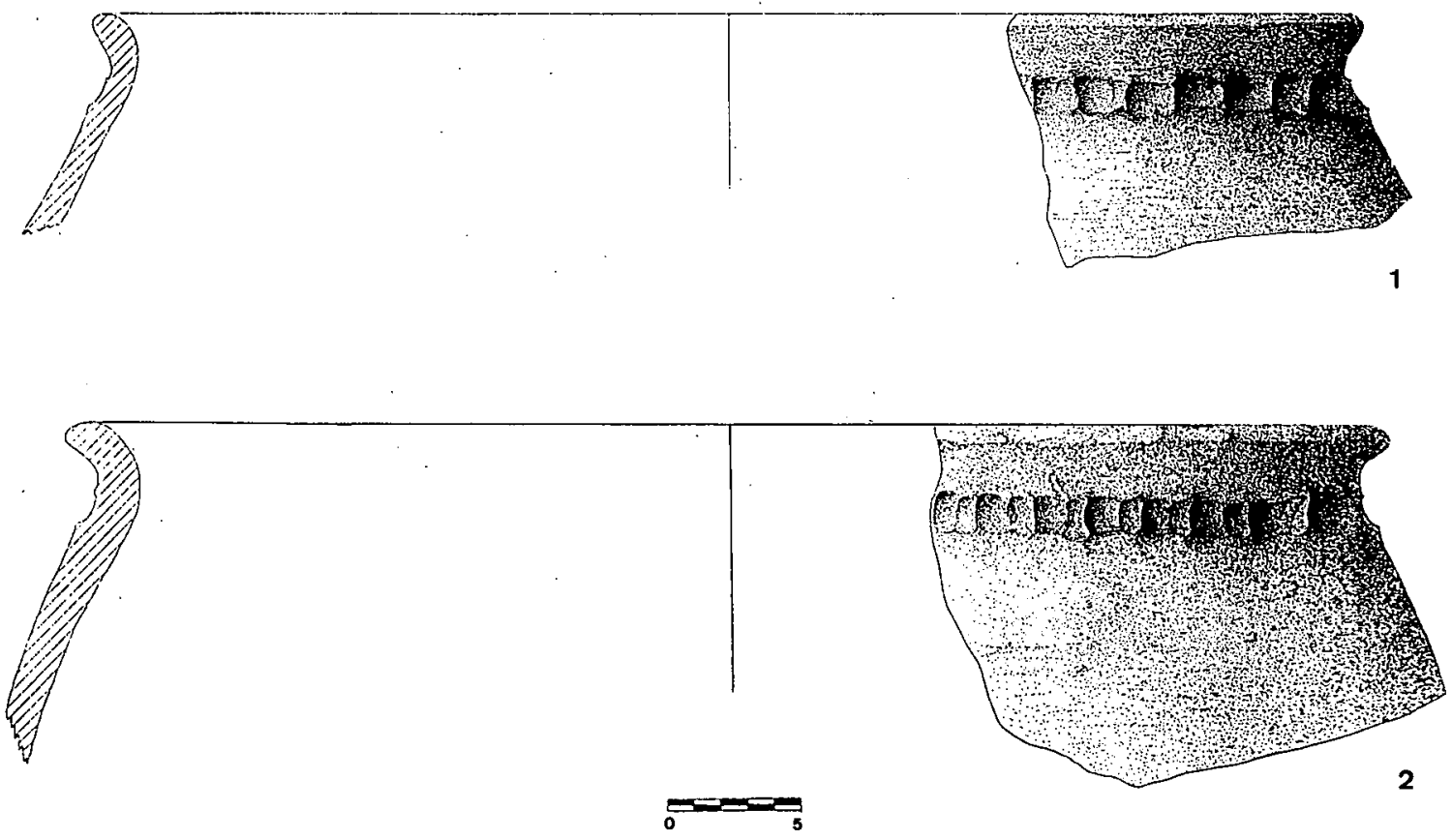

Fig. 4: Cerámica con decoración digitada. 

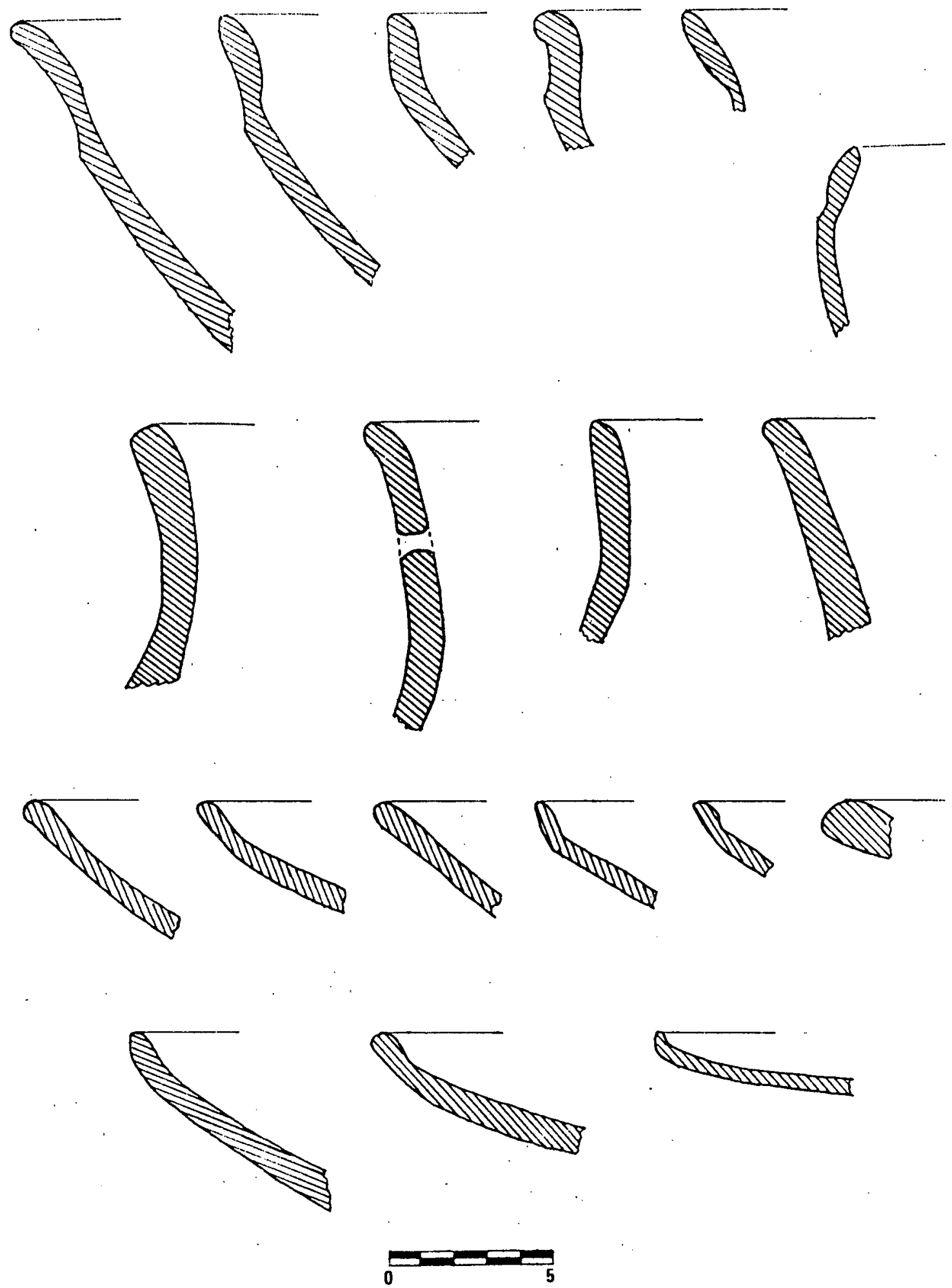

Fig. 5: Cerámica bruñida sin decoración. 


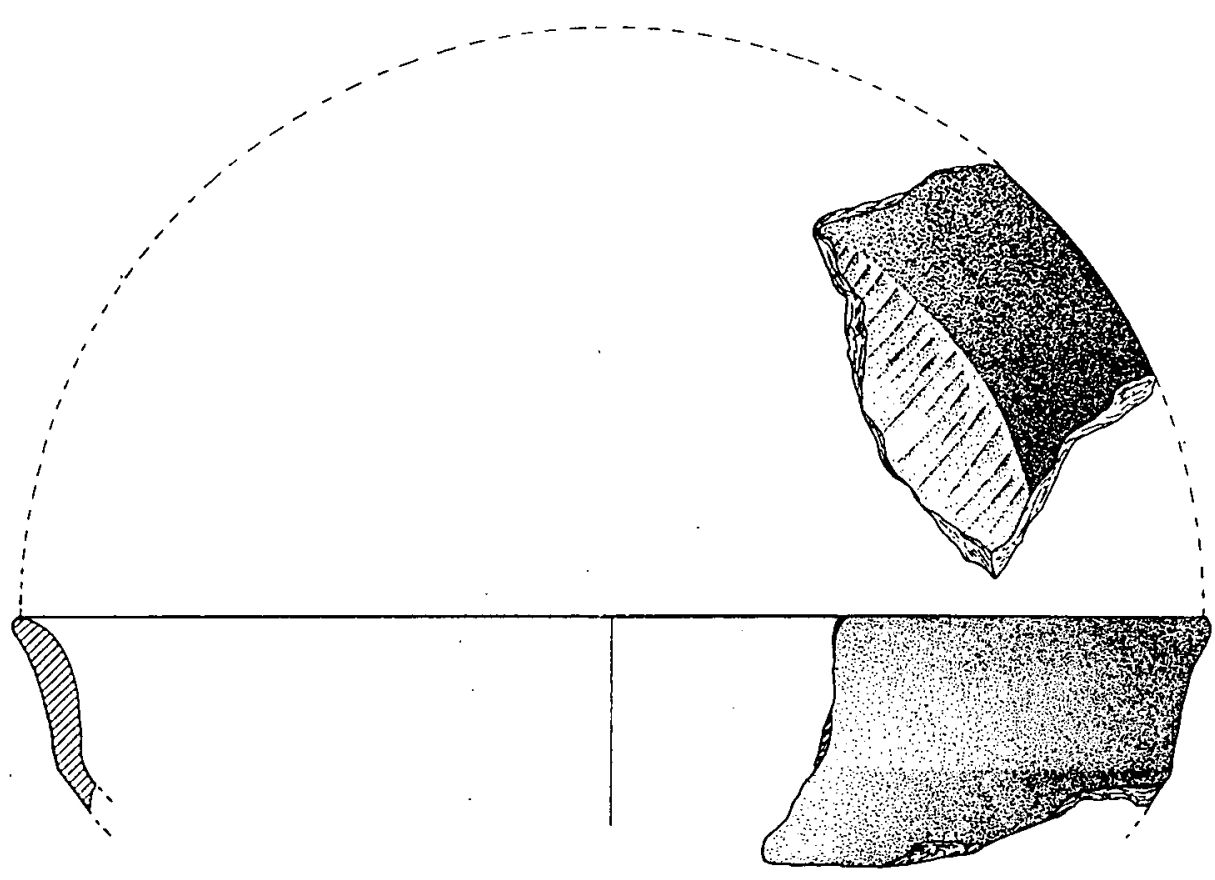

1

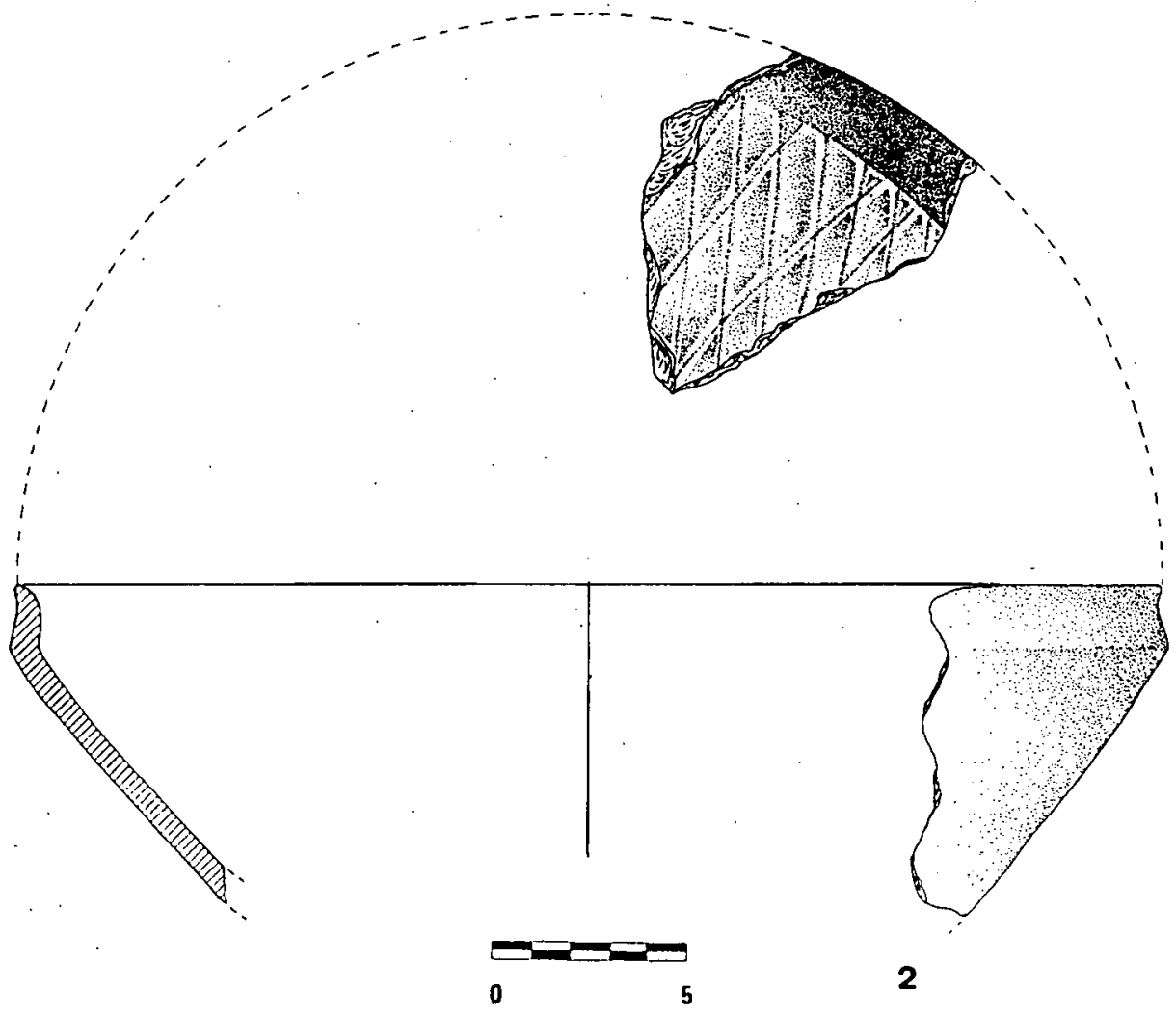

Fig. 6: Cerámica con decoración bruñida. 


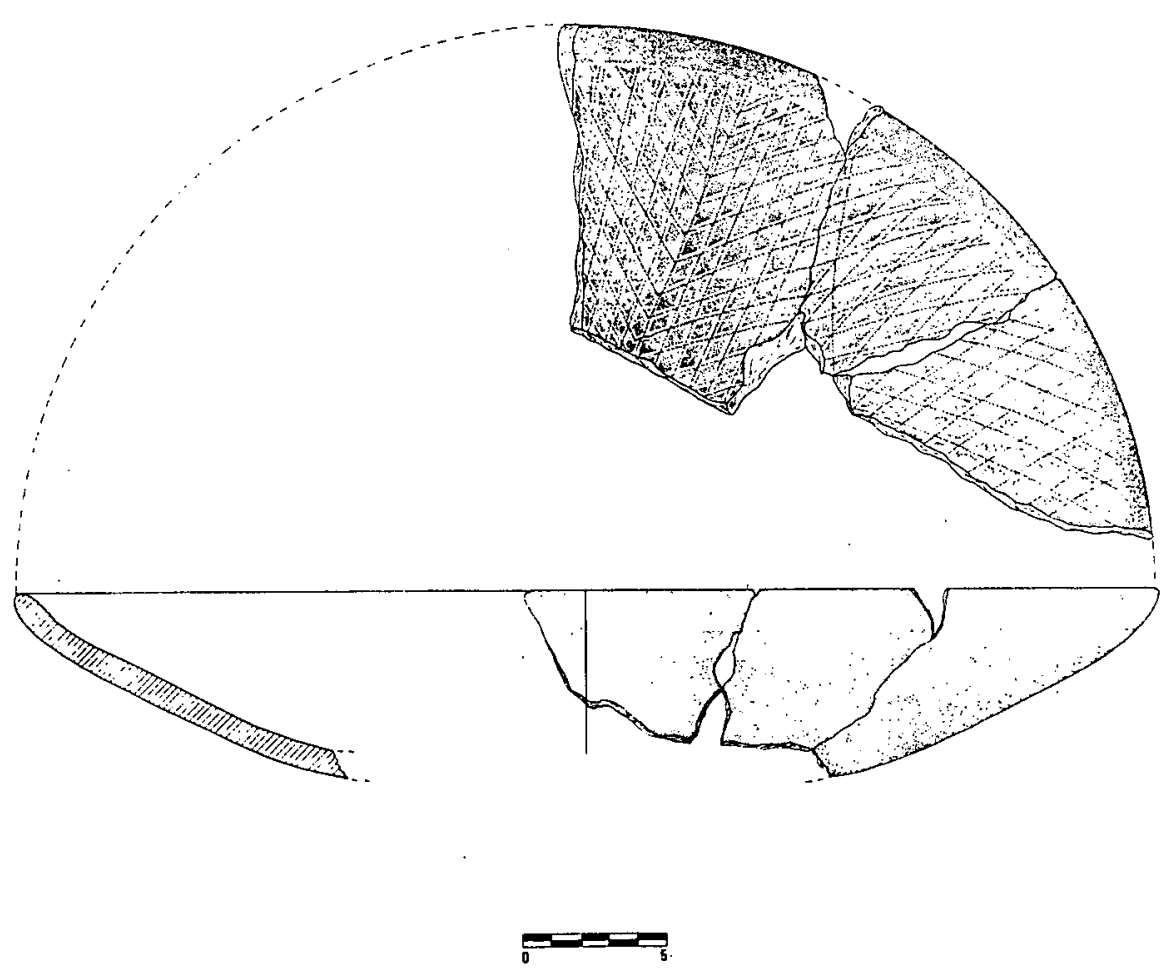

Fig. 7: Cerámica con decoración bruñida.

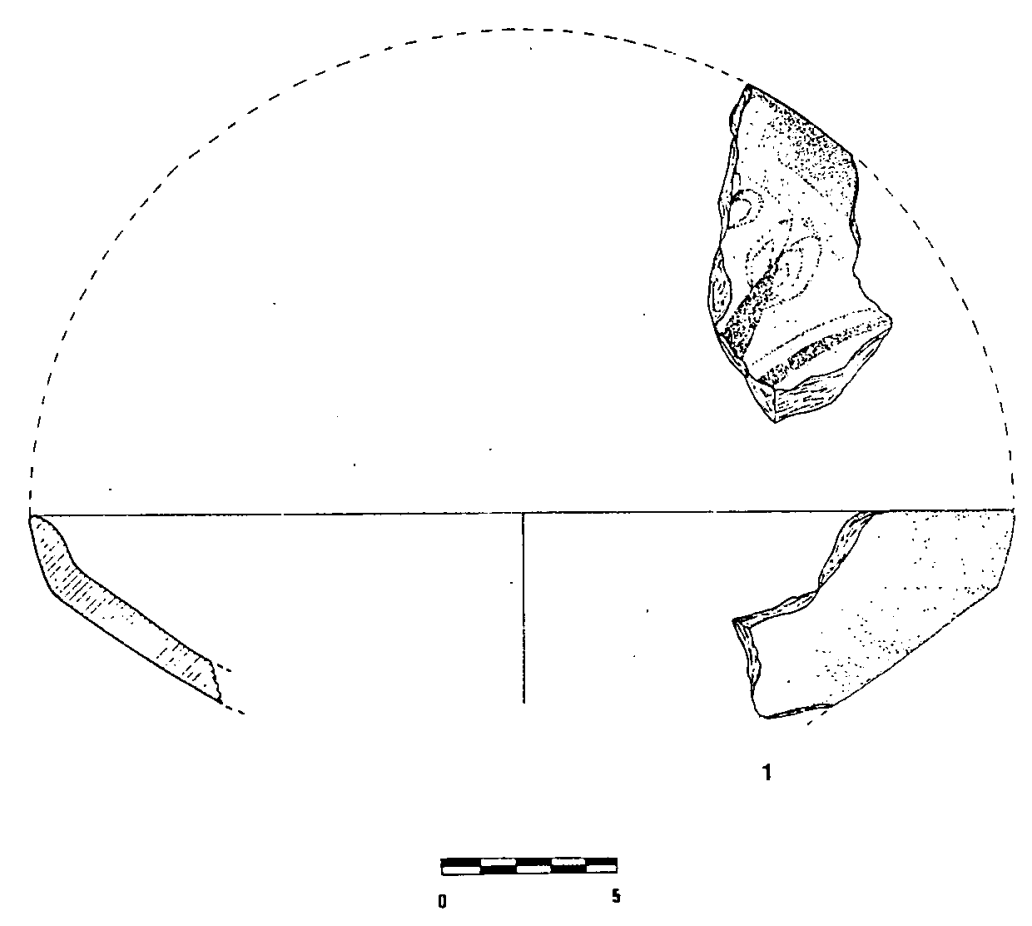

Fig. 8: Cerámica con decoración bruñida. 

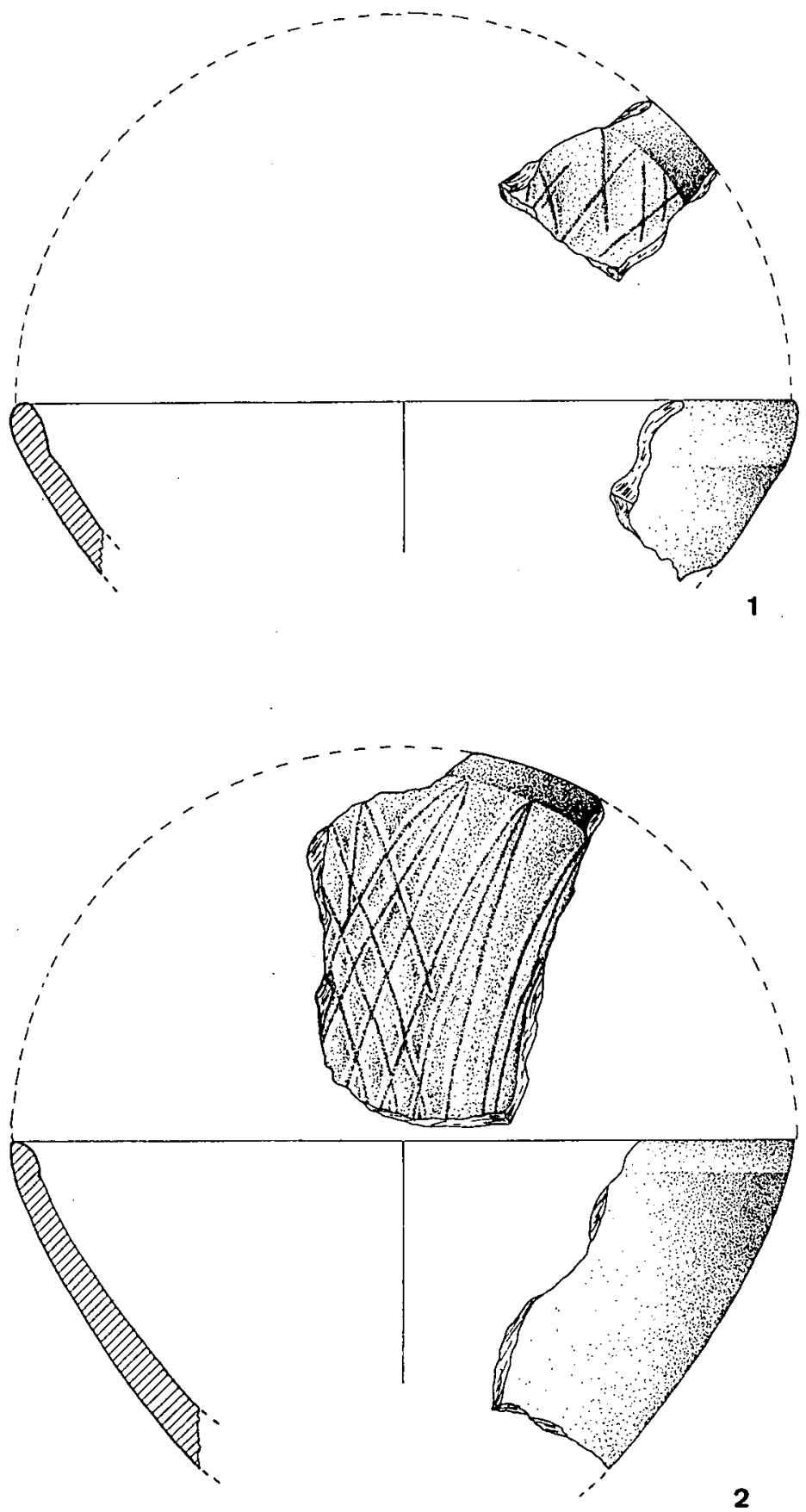

\section{i}

Fig. 9: Cerámica con decoración bruñida. 


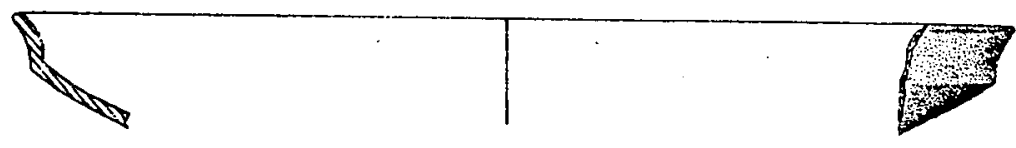

1
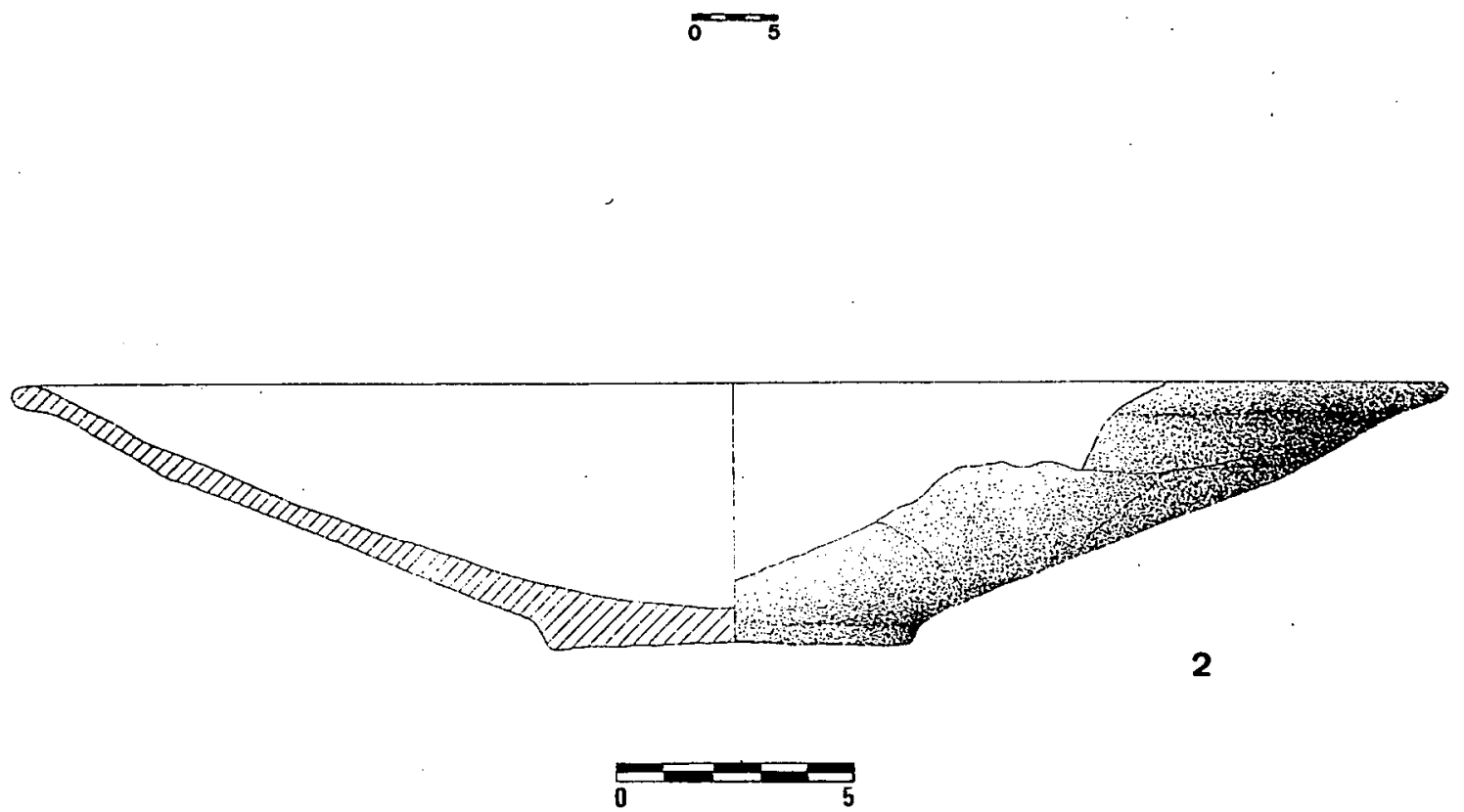

Fig. 10: 1. Cerámica gris; 2. Cerámica bruñida sin decoración. 

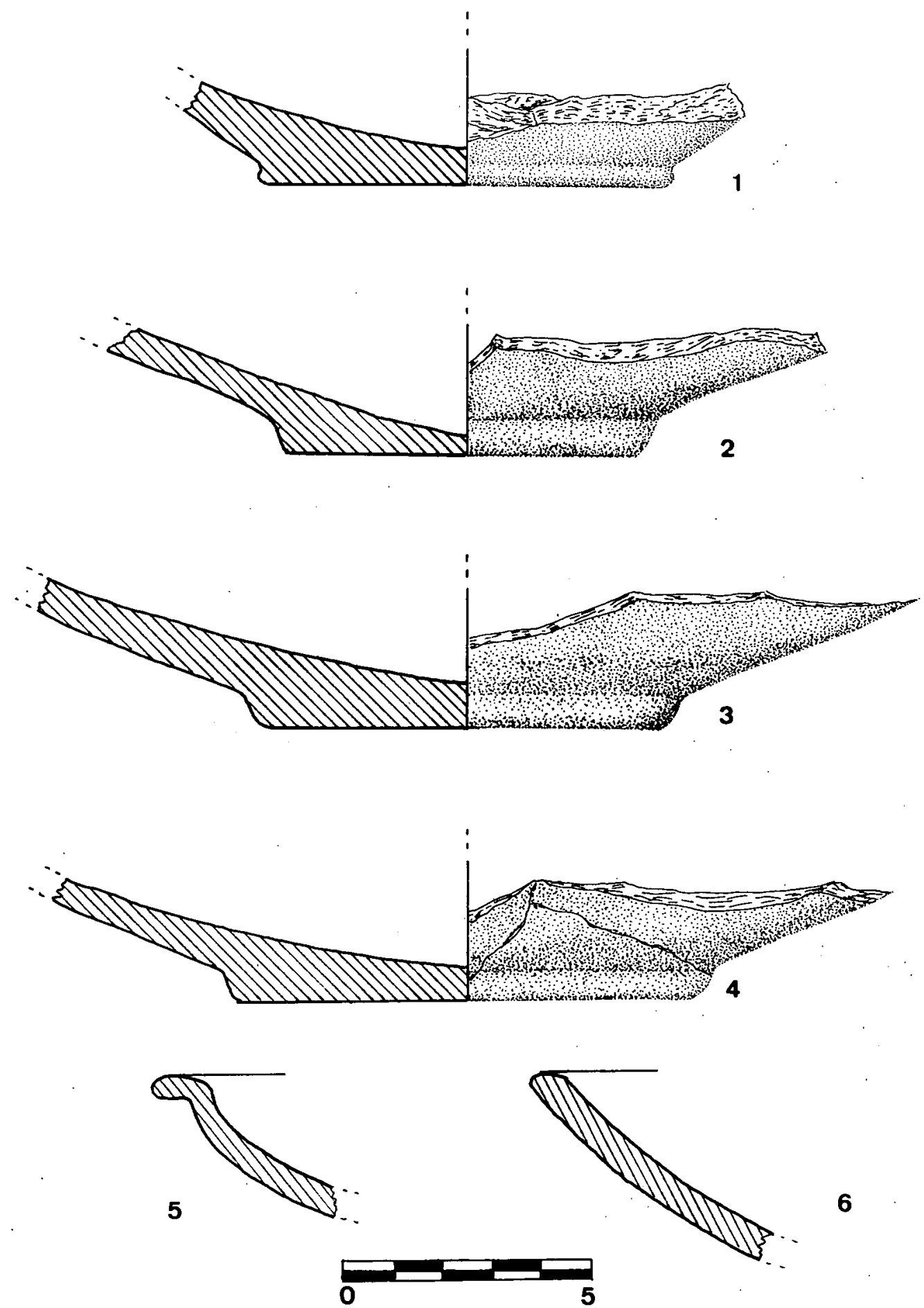

Fig. 11: Cerámica gris. 

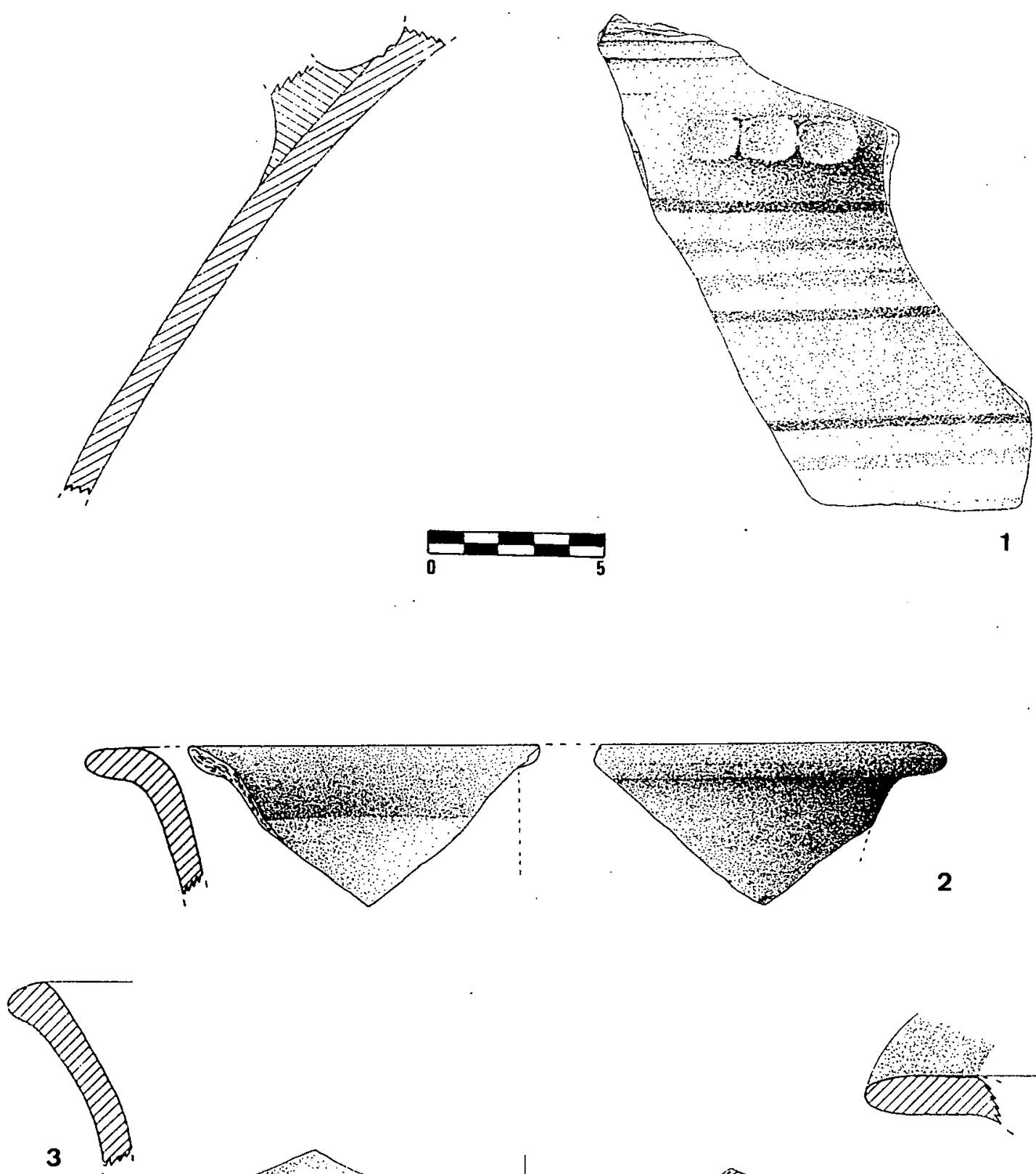

1

2

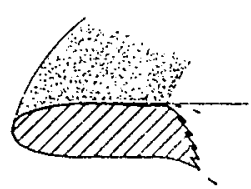

4

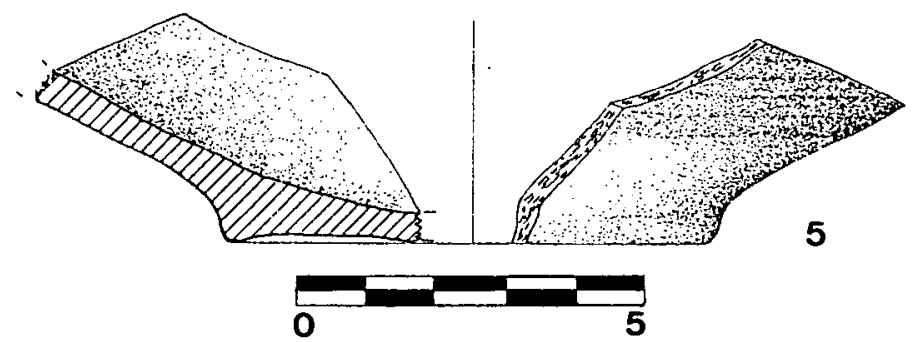

Fig. 12: Cerámica con decoración pintada. 

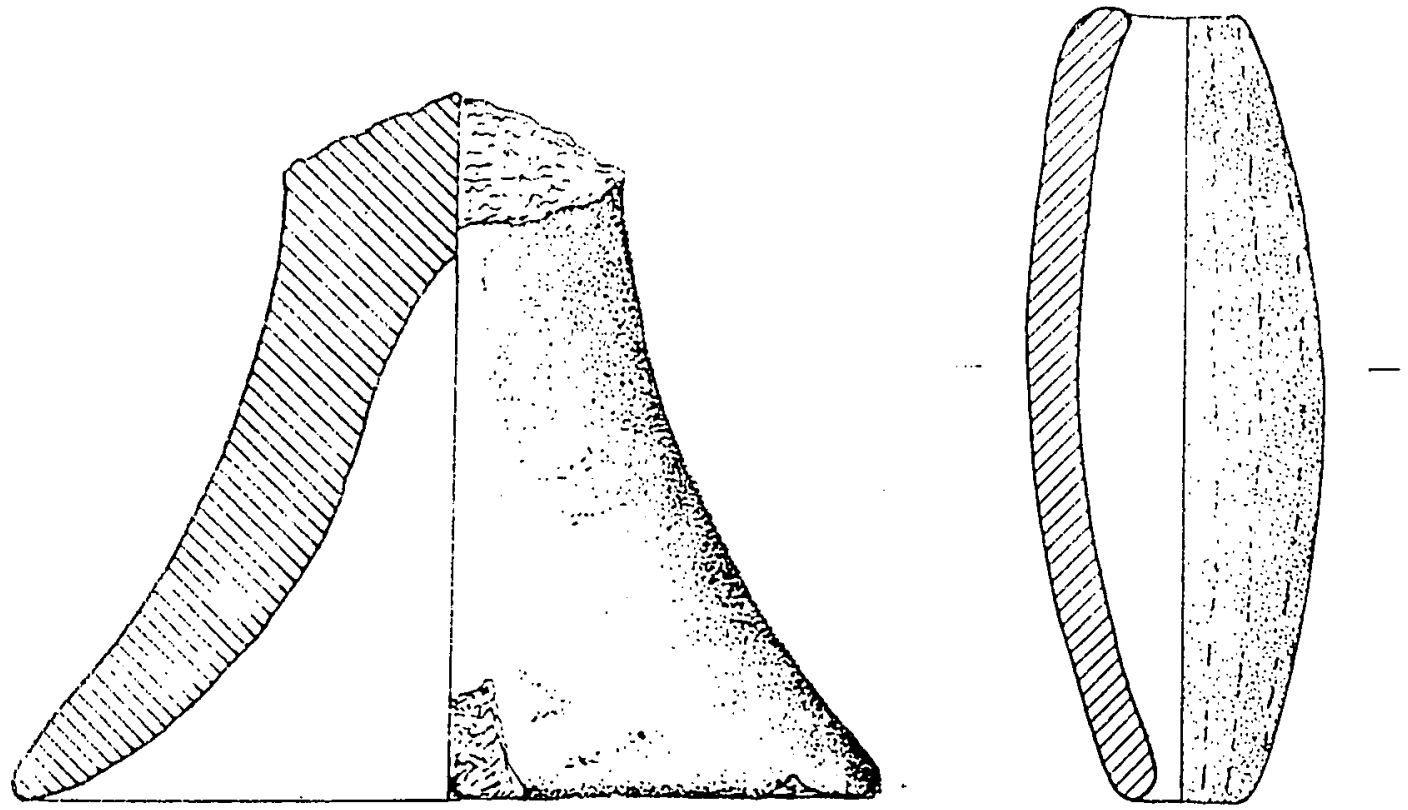

1

2
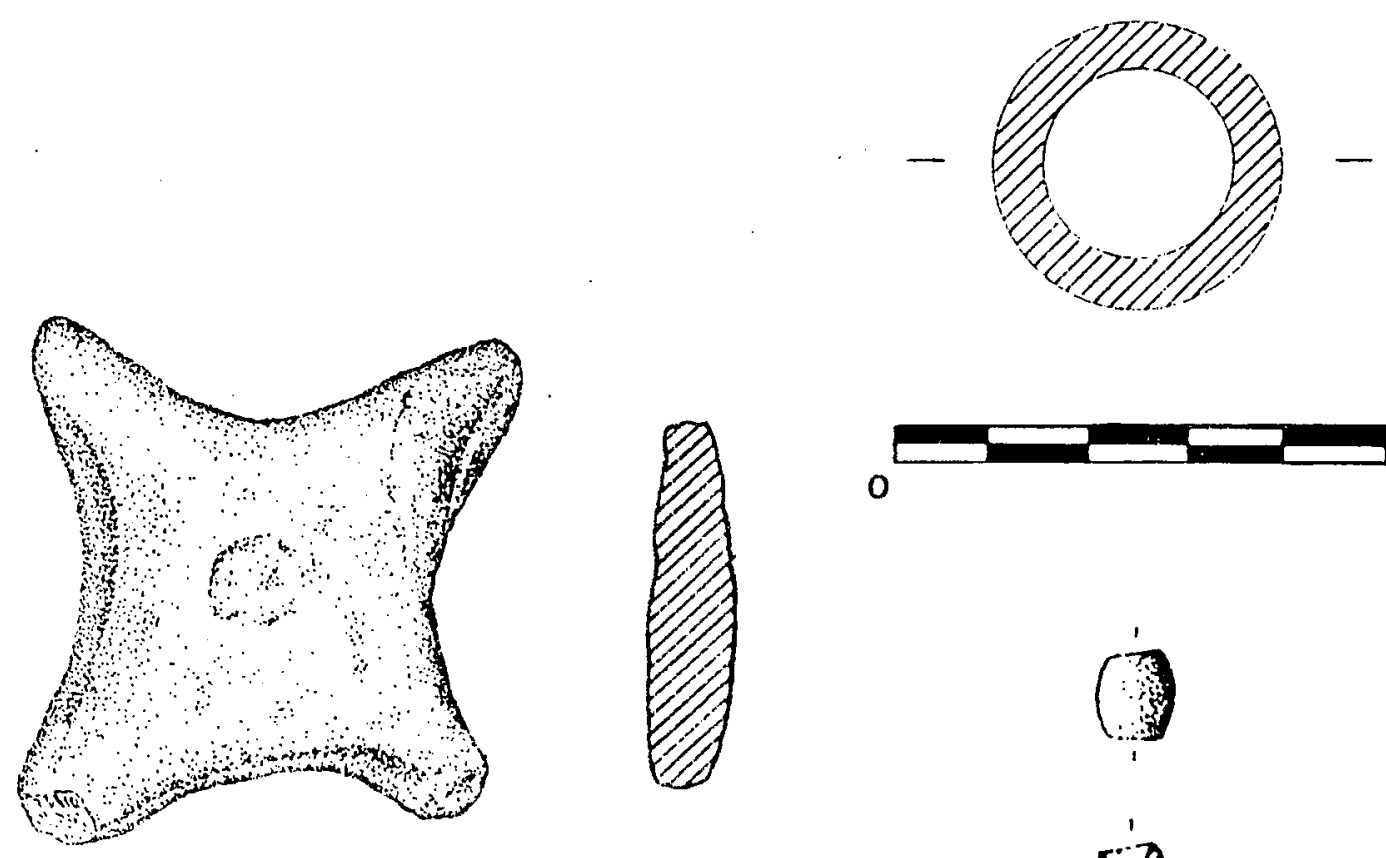

0<smiles>[131I-]</smiles>

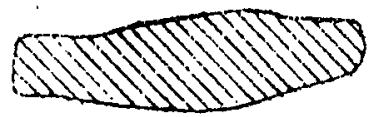

3

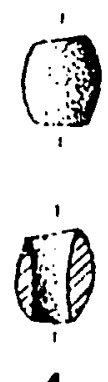

4

Fig. 13: Pie de copa (I), cuenta de piedra (4) y otros objetos de función desconocida (2 y 3). 

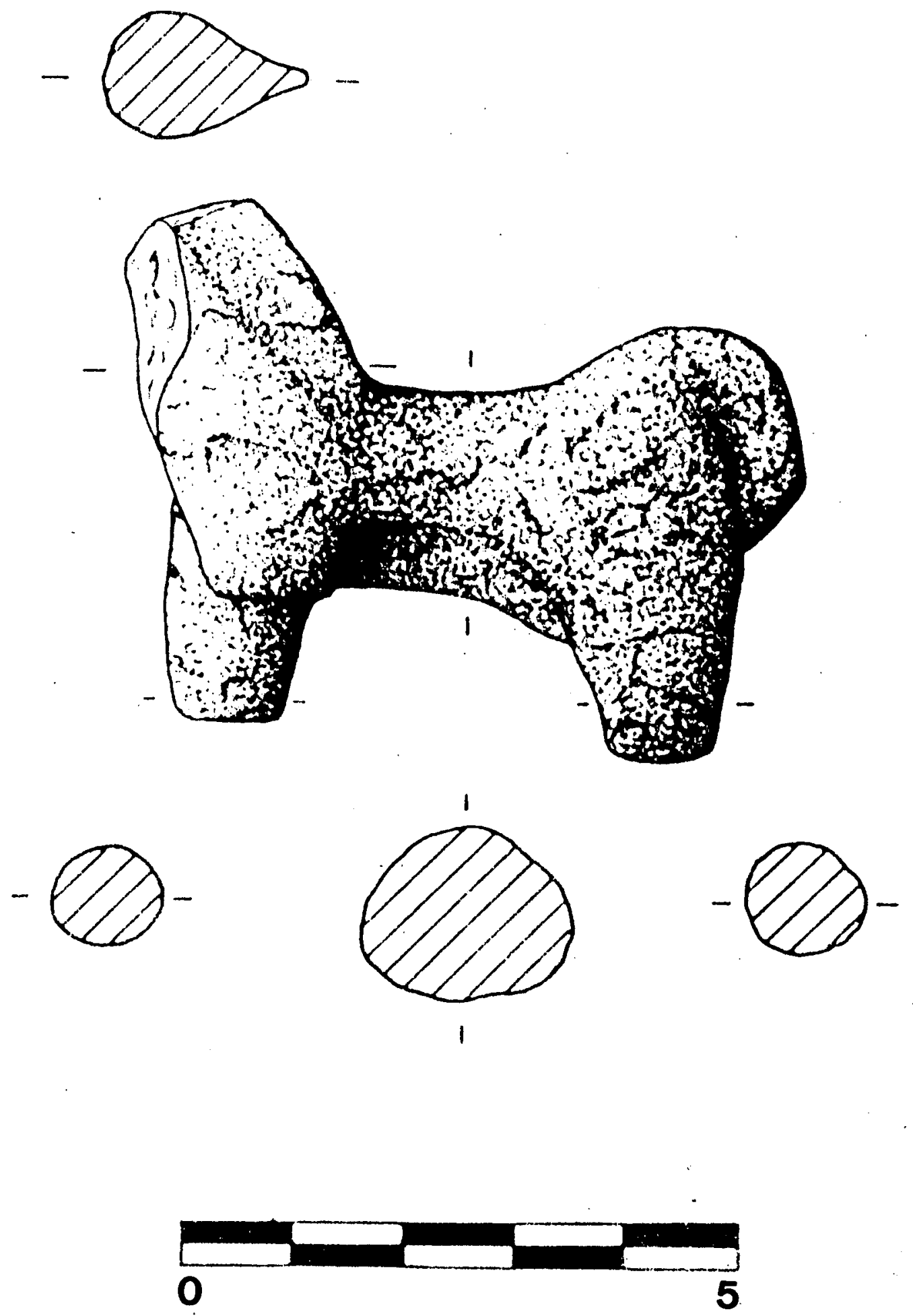

Fig. 14: Figura zoomorfa. 